\title{
PAPAYA SEED EXTRACT LOWERS SPERM CONCENTRATIONS, MOTILITY AND VIABILITY IN MALE MICE
}

\author{
Reryd Arindany Wiryawan ${ }^{1}$, Reny I'tishom ${ }^{2}$, Sri Purwaningsih ${ }^{3}$ \\ ${ }^{1}$ Medical Doctor Study Program, ${ }^{2}$ Department of Medical Biology, \\ ${ }^{3}$ Department of Medical Pharmacology, Faculty of Medicine, Universitas Airlangga, Surabaya
}

\begin{abstract}
ABSTRAK
Indonesia adalah negara berkembang dengan penduduk padat, sehingga pemerintah menjalankan program KB (Keluarga Berencana) yang sebagian besar sasarannya adalah perempuan. Kontrasepsi yang ditujukan untuk perempuan secara bertahap mulai berkembang adalah pil KB dan pemasangan IUD (Intra Uterine Device). Sampai saat ini kontrasepsi bagi pria yang dianggap mapan adalah kondom dan vasektomi. Pengembangan obat herbal yang murah dan terjangkau dapat dikonsumsi dalam jangka panjang dengan efek samping yang kurang bermakna. Biji pepaya (Carica papaya) adalah salah satu dari banyak tanaman yang digunakan oleh masyarakat untuk mengatasi cacingan, pencahar menstruasi, dan abortivum. Buah, daun, dan biji pepaya juga mengandung carpaine, suatu alkaloid yang digunakan sebagai antihelmintik. Biji pepaya yang dapat dimakan dan berrasa pedas di India digunakan untuk kontrasepsi. Kandungan alkaloid dalam biji pepaya menyebabkan pepaya dapat menjadi tanaman herbal untuk antifertilitas pada pria yang dapat dilihat pengaruhnya pada kualitas spermatozoa. Senyawa alkaloid yang terkandung dalam biji pepaya dapat mengganggu hormon testosteron, yang akan merusak kualitas sperma, sehingga dapat digunakan sebagai alat kontrasepsi. (FMI 2015;51:252-256)
\end{abstract}

Kata Kunci: papaya, Carica papaya, kualitas sperma, Mus musculus, ekstrak

\begin{abstract}
Indonesia is a developing country with a dense population, so the government carry on KB (Family Planning) program in which the targets are mostly women. Contraceptives are intended for women are birth control pills and IUD (Intra Uterine Device), whereas until now the contraceptive for men who are considered well-established are condom and vasectomy. Thus, the development of herbal medicine, which is cheap and affordable, makes it possible to be consumed in a long term with less meaningful side effects. Papaya seeds (Carica papaya) is one of the many plants used by communities to eradicate intestinal worms, menstrual laxative, and abortivum. Empirically papaya fruit, leaves, and seeds of papaya also contains carpaine, an alkaloid which is used as anthelmintic. Papaya seeds, which are edible and spicy in India are used for contraception. Alkaloid content in seeds of papaya can be antifertility herbal plants for males that can be measured from the quality of spermatozoa. Alkaloid compounds contained in papaya seeds can disrupt the hormone testosterone, which would interfere the sperm quality, making papaya seed potential to become a candidate for contraceptive. (FMI 2015;51:252-256)
\end{abstract}

Keywords: papaya, Carica papaya, sperm quality, Mus musculus, extract

Correspondence: Reryd Arindany Wiryawan, Medical Doctor Program, Faculty of Medicine, Universitas Airlangga, J1 Prof dr Moestopo 47, Surabaya 60131, Indonesia.

\section{INTRODUCTION}

Indonesia is a developing country with a population of 222.2 million people (Anonymous 2007), was ranked as the fourth highest population density after the PRC, India and the United States. Contraception is aimed at women slowly began to evolve, example is the birth control pill and IUD insertion (Intra Uterine Device) (BKKBN 2006), whereas until now contraceptives for men who are considered stable are condoms and vasectomy. However, the use of condoms as a contra-ceptive cause complaints, often have side effects. Thus, by developing herbal medicines, besides being cheap and affordable, these herbal medicines when consumed in a long period of time tend to not give significant side effects.

The quality of spermatozoa can be determined from sperm motility, sperm concentration, and sperm viability that can be influenced by the temperature of the genital organs, the adequacy of nutrition, and hormonal regulation. The hypothalamus secretes gonadotrophin releasing hormone signal, which stimulates the anterior pituitary to secrete and release luteinizing hormone (LH) and follicle stimulating hormone (FSH). LH stimulates Leydig cells to activate the synthesis of pregnenolone from cholesterol. Synthesized testosterone has a paracrine effect on the Sertoli cells, where testosterone plays an important role in facilitating spermato- 
genesis. Disruption of this pathway can reduce the function of the Leydig cells, and stimulates the reduction of testosterone secretion. The content of this alkaloid compounds having estrogenic activity that can inhibit glandular secretion and release of gonadotropins (Satriyasa 2005). This study want to prove whether the seed extract of papaya (Carica papayas) which has a content of alkaloid compounds, have a preventive effect on male fertility or contraception. From this study is expected to obtain information and scientific data on the potential of papaya seed extract as anti-fertility.

\section{MATERIAL AND METHODS}

The study design used was a type of experimental studies with randomized methods, post-test only design. This research was conducted at the Faculty of Medicine, University of Airlangga. Experimental animals kept in cages Pharmacology Laboratory experiments. Papaya seed extract obtained in the Research and Industrial Consultancy (Laboratory of Research and Industrial Consultancy) Surabaya. The sample of the study was male mice between 2-3 months of age weighing between 20-30 grams. Animal experiments 28 male mice (Mus musculus) were obtained from Federer formula, rounded to 7 . Divided into four groups, one control group (C) and three treatment groups (P1, P2, P3).

Preparation of extracts of papaya seeds: seeds of papaya (Carica papaya) that has been dried, the powder is made. The dried fruit powder $(1500 \mathrm{~g})$ separately was macerated with methanol by extract evaporation with vacuum techniques, and then the viscous extract was obtained. Papaya seed extract given orally with sonde once a day. On day 7, mice were sacrificed with chloroform in anesthesia, both its left and right epididymis were lifted, put in $3 \mathrm{ml}$ of PBS (Phosphate Buffer Salline). Furthermore, the epididymis was destroyed by shredding scissors eye to form a homogeneous suspension of spermatozoa.

Spermatozoa concentration (number of sperm/ml) was determined using the haemovytometer method. If the preliminary investigation indicates that the number of spermatozoa is very solid, the dilution of preparation should be adjusted. 1: 50 dilution is more appropriate, performed with leukocyte Thoma pipette. Preparations that have been diluted and stirred homogeneous, dropped into the room count improved Neubauer and covered with glass cover.

Sperm motility was determined by measuring the velocity of spermatozoa in a Neubauer counting chamber. One drop of sperm suspension in PBS solution was dropped in the chamber count. Under the microscope magnification of 4000x, travel time of the moving spermatozoa in a straight micro-city within $0.05 \mathrm{~mm}$ recorded. Speed was in $\mathrm{mm} / \mathrm{sec}$. Viability of spermatozoa was used to determine death or life immotil spermatozoa. First mix 1 drop of fresh semen with 1 drop of $0.5 \%$ eosin solution on object glass and cover with a cover glass. After 2 minutes, seeit with a light microscope (400x magnification). Count live spermatozoa (white does not absorb color) and dead spermatozoa (absorbs red color). Calculate the percentage, the number of live spermatozoa: the number of live + dead spermatozoa.

The data obtained will be analyzed as follows: a descriptive analysis to present data from each experimental group, normality analysis to determine the distribution of the data obtained before treatment, homogeneity analysis to determine the variants of the data prior to treatment; Anova analysis to determine the mean of each difference between groups; comparative analysis to determine differences between the control group to the treatment group, the degree of significance set at $\mathrm{p}<0.05$.

If the test results showed that the data for each variable that includes the average number of A spermatogonia cells before treatment lies in the normal distribution and homogeneous ( $p>0.05)$, then the results of the analysis will continue with trials onewayAnova and LSD (Least Significant Difference) between groups.

\section{RESULTS}

Tail of 28 samples were divided into four groups by the number of each of the seven mice. Based on the results of 28 measurements of sperm cells of mice (Mus musculus), the data obtained levels of concentration, motility, and viability of mice is shown in Table 1. 
Papaya Seed Extract Lowers Sperm Concentrations, Motility and Viability (Reryd Arindany Wiryawan et al)

Table 1. Sperm cells quality in mice (Mus musculus)

\begin{tabular}{|c|c|c|}
\hline \multicolumn{3}{|c|}{ Control (CMC + Distilled water) } \\
\hline Concentration (million/cc) & Motility $(\mathrm{A}+\mathrm{B})(\%)$ & Viability (\%) \\
\hline 165 & 66 & 5 \\
\hline 147 & 60 & 11 \\
\hline 179 & 74 & 13 \\
\hline 177 & 49 & 10 \\
\hline 183 & 48 & 14 \\
\hline 164 & 52 & 25 \\
\hline 180 & 43 & 28 \\
\hline \multicolumn{3}{|c|}{ Treatment I (20mg/KgBW/day + CMC + Distilled water $)$} \\
\hline Concentration (million/cc) & Motility $(\mathrm{A}+\mathrm{B})(\%)$ & Viability $(\%)$ \\
\hline 99 & 25 & 30 \\
\hline 95 & 20 & 38 \\
\hline 92 & 17 & 32 \\
\hline 97 & 23 & 46 \\
\hline 92 & 17 & 43 \\
\hline 99 & 24 & 61 \\
\hline 95 & 21 & 40 \\
\hline \multicolumn{3}{|c|}{ Treatment II $(40 \mathrm{mg} / \mathrm{KgBW} / \mathrm{day}+\mathrm{CMC}+$ distilled water $)$} \\
\hline Concentration (million/cc) & Motility (A+B) (\%) & Viability (\%) \\
\hline 85 & 5 & 33 \\
\hline 74 & 3 & 28 \\
\hline 71 & 3 & 34 \\
\hline 81 & 6 & 37 \\
\hline 71 & 5 & 48 \\
\hline 72 & 6 & 55 \\
\hline 83 & 6 & 39 \\
\hline \multicolumn{3}{|c|}{ Treatment III (60mg/KgBW/day + CMC + distilled water) } \\
\hline Concentration (million/cc) & Motility $(\mathrm{A}+\mathrm{B})(\%)$ & Viability $(\%)$ \\
\hline 69 & 3 & 95 \\
\hline 63 & 3 & 88 \\
\hline 64 & 4 & 94 \\
\hline 62 & 1 & 95 \\
\hline 70 & 1 & 93 \\
\hline 63 & 0 & 93 \\
\hline 64 & 0 & 98 \\
\hline
\end{tabular}

The data were analyzed sperm concentration after administration of papaya seed extract (Carica papaya). Data obtained from observations on each histological preparations in accordance with the treatment, replicates and doses used. The results of sperm concentration in mice (Mus musculus) (Table 2). In this study, the difference in the average value of each group. Sperm concentration data normality test obtained $\mathrm{p}>0.005$, it can be concluded that the data were normally distributed except for the concentration of the third treatment, where $\mathrm{p}<0.05$. The results of sperm motility in mice (Mus musculus) shown in Table 3. Viability data were taken is the number of spermatozoa head is red, the more the number of spermatozoa in red decreased viability. The results of the viability of spermatozoa in mice (Mus musculus) is shown in Table 4. 
Table 2. Average concentration of sperm in mice (Mus musculus) after administration of extract of papaya seeds (Carica papaya)

\begin{tabular}{|c|c|c|c|c|c|c|c|}
\hline & \multirow[b]{2}{*}{ Group } & \multicolumn{3}{|c|}{ Kolmogorov-Smirnov $^{\mathrm{a}}$} & \multicolumn{3}{|c|}{ Shapiro-Wilk } \\
\hline & & Statistic & Df & Sig. & Statistic & Df & Sig. \\
\hline \multirow[t]{4}{*}{ Concentration } & 0 & .260 & 7 & .169 & .869 & 7 & .180 \\
\hline & I & .174 & 7 & $.200^{*}$ & .885 & 7 & .250 \\
\hline & II & .244 & 7 & $.200^{*}$ & .839 & 7 & .097 \\
\hline & III & .338 & 7 & .015 & .804 & 7 & .045 \\
\hline
\end{tabular}

Notes:

P $0=$ Treatment control

P I = Treatment of papaya seed extract at a dose $20 \mathrm{mg} / \mathrm{KgBW}$

P II = Treatment of papaya seed extract at a dose $40 \mathrm{mg} / \mathrm{KgBW}$

$\mathrm{P}$ III = Treatment of papaya seed extract at a dose $60 \mathrm{mg} / \mathrm{KgBW}$

Table 3. Average sperm motility in mice (Mus musculus) after administration of extract of papaya seeds (Carica papaya)

\begin{tabular}{|ll|l|l|l|l|l|l|}
\hline & & \multicolumn{3}{|l|}{ Kolmogorov-Smirnova } & \multicolumn{2}{l|}{ Shapiro-Wilk } \\
\cline { 2 - 8 } & Group & Statistic & Df & Sig. & Statistic & Df & Sig. \\
\hline \hline Motility & 0 & .208 & 7 & $.200^{*}$ & .848 & 7 & .118 \\
& I & .108 & 7 & $.200^{*}$ & .978 & 7 & .949 \\
III & .173 & 7 & $.200^{*}$ & .922 & 7 & .482 \\
III & .360 & 7 & .007 & .664 & 7 & .001 \\
\hline
\end{tabular}

Notes:

$\mathrm{P} 0=$ treatment control

$\mathrm{P} \mathrm{I}=$ Treatment of papaya seed extract at a dose $20 \mathrm{mg} / \mathrm{KgBW}$

P II = Treatment of papaya seed extract at a dose $40 \mathrm{mg} / \mathrm{KgBW}$

P III = Treatment of papaya seed extract at a dose $60 \mathrm{mg} / \mathrm{KgBW}$

Table 4. Average viability of spermatozoa in mice (Mus musculus) after administration of extract of papaya seeds (Carica papaya)

\begin{tabular}{|ll|l|l|l|l|l|l|}
\hline & \multicolumn{3}{|l|}{ Kolmogorov-Smirnov } & \multicolumn{2}{l|}{ Shapiro-Wilk } \\
\cline { 2 - 8 } & Group & Statistic & Dr & Sig. & Statistic & Dr & Sig. \\
\hline \hline Viability & 0 & .269 & 7 & .136 & .898 & 7 & .318 \\
& & .186 & 7 & $.200^{*}$ & .920 & 7 & .472 \\
& I & .220 & 7 & $.200^{*}$ & .932 & 7 & .568 \\
II & .264 & 7 & .149 & .914 & 7 & .427 \\
III & &
\end{tabular}

Notes:

P $0=$ Treatment control

P I = Treatment of papaya seed extract at a dose $20 \mathrm{mg} / \mathrm{KgBW}$

P II = Treatment of papaya seed extract at a dose $40 \mathrm{mg} / \mathrm{KgBW}$

P III $=$ Treatment of papaya seed extract at a dose $60 \mathrm{mg} / \mathrm{KgBW}$

\section{DISCUSSION}

Alkaloid compounds contained in papaya seeds can disrupt the hormone testosterone, which would interfere with the quality of sperm (Winarno 2007). Alkaloid content of the papaya fruit have estrogenic reaction that affects a decrease in the hormone testosterone (Winarno
2007). By the way inhibit gland gonadotropin $(\mathrm{GnRH})$ for secretion. Because GnRH inhibited the anterior pituitary gland LH secreted not to inhibit the synthesis of testosterone.

Mechanism of action of alkaloids, estrogenic effects will suppress the hypothalamus and anterior pituitary 
hormones causing GnRH and gonadotropins (FSH and LH) are inhibited. This hormone stimulates the Leydig cells to produce testosterone. Testosterone with FSH in the seminiferous tubules to stimulate spermatogenesis. Spermatogenesis is the formation of spermatozoa, with changes in spermatogonia to spermatocytes. With the disruption of the maturation process of spermatozoa spermatogonesis also impaired, resulting in decreased sperm quality. Which includes the quality of motility of spermatozoa is, concentration and viability.

The statistical result shows that there are significant differences in sperm concentration, motility, and viability between the control group and all groups were given treatment. Among the group given the extract of papaya seeds with different doses significant difference. Density at a given exposure group papaya seed extract degenerate than the control group which was not given exposure to papaya seeds. It shows estrogenic effects that will suppress the hypothalamus and anterior pituitary, causing GnRH and gonadotropin hormone (FSH and LH) causing stunted and did not stimulate the Leydig cells to produce testosterone for spermatogenesis sperm function so that the number of spermatozoa concentration decreased.

Motility values are entered in the data is the number of moving sperm cells in each treatment progressive. In the results chart that can be found in appendix there is a decrease in the number of sperm cells that move in a progressive increase in the proportion to the dose.

The decrease in sperm motility due to impaired spermatogenesis, spermatogonia, through dual mitotic and meiotic divisions that develop into mature spermatozoa. Briefly, this process can be divided into four stages. First, type A spermatogonia undergo mitosis, so the renewal of germline stem cells and type B spermatogonia, which continues to differentiation. Second, type B spermatogonia undergo meiosis, generate haploid round spermatids. Furthermore, spermiogenesis occurs, where round spermatids to motile spermatozoa maturity without undergoing further cell division. Spermiogenesis includes the formation of condensation, nuclear acrosome, and extensive cellular reorganization including the development of the sperm tail. Finally, the interaction with Sertoli cells mediate spermiation process, whereby cytoplasmic material will be removed from spermatids and mature sperm are released into the lumen of the seminiferous tubules. This entire process is under endocrine regulation.
Motility of spermatozoa can be disrupted by the presence of alkaloid compounds that are esterogenic to disrupt spermiogenesis so that development does not occur with perfect sperm.

Viability values are entered in the data is the number of sperm cells that silence the red headed at each treatment. In the results chart that can be found in appendix there is an increase in the number of sperm cells that silence the red head is proportional to the increase in dose. In the graph it can be seen also, that there is no significant difference between treatments in the II and III.

Estrogenic effects that suppress the hypothalamus and anterior pituitary, causing hormone GnRH and the gonadotropins (FSH and $\mathrm{LH}$ ) causing stunted and did not stimulate the Leydig cells to produce testosterone for spermatogenesis sperm function. Sperm viability is an important indicator of the capacity of spermatozoa that occurs when spermiogenesis. Sperm viability is a reflection of complete spermatogenesis and sperm capacitation before spermiation. Incomplete maturation of gametes caused by hormonal disorders can reduce the viability of spermatozoa.

\section{CONCLUSION}

Papaya seed extract at a dose $20 \mathrm{mg} / \mathrm{KgBW} /$ day lowers sperm concentrations, motility and viability in male mice.

\section{REFERENCES}

Anonim (2007). Statistik Indonesisa 2007, Jakarta, Badan Pusat Statistik

BKKBN (2006). Memilih Kontrasepsi. Available from www.bkkbn.go.id. Accessed June 28, 2011

Satriyasa B (2005). Fraksi heksan dan fraksi metanol ekstrak biji pepaya muda (Carica papaya) dapat menghambat spermatogonia A mencit jantan (Mus musculus). Disertation. Universitas Udayana, Denpasar

Winarno (1997). Informasi tanaman Obat untuk Kontrasepsi Tradisional. Available from http://www. scribd.com/doc/24845801/Informasi-Tanaman-ObatUntuk-Kontrasepsi-Tradisional. Accessed June 1, 2010 